\title{
Implementation of hybrid pollution control techniques to regulate the metal finishing industries in the Ethekwini Municipality
}

\author{
D Braum \\ Water and Sanitation, eThekwini Municipality, PO Box 1038, Durban 4000, South Africa
}

\begin{abstract}
The preparation of the Durban Metro Sewage Disposal Bylaws forced a closer investigation with respect to metals in the different sewer catchments in the then Durban Metro area. The status in 1999 found few Metal Finishing Industries complying with all environmental regulations and principles, high heavy metal concentrations in some of the sewage work sludges and illegal discharges of untreated heavy metal industrial effluents to the receiving environments.

This paper describes the implementation and uses of hybrid pollution control techniques to regulate the metal finishing industries to reduce their environmental impact. The techniques used are a combination of environmental auditing tools, cleaner production, formation of and co-operation between industry associations and the local authority, waste minimisation groups, cost based incentives and structured enforcement of the bylaws and agreements.

These techniques have been developed and used over the last four years, and have shown success in reducing the environmental impacts and improving relationships between industry and the municipality. This allowed for a better participative approach to setting new standards to be achieved and a more sustainable environment in which both the metal finishing industries and municipality can operate.
\end{abstract}

\section{Introduction}

In November 1996 the Durban Metropolitan Pollution Division was formed from several local authorities. Various bylaws from Durban, Pinetown, Amanzimtoti, New Germany, Tongaat, Verulam and DSB had to be enforced. Each of these bylaws had their own standards for heavy metal discharge limits to the corresponding wastewater treatment works. Varying pre-treatment, enforcement, sampling and analytical methods were also practiced in these areas. On the $13^{\text {th }}$ of May 1999 the Durban Metropolitan Sewage Disposal Bylaws were promulgated creating a single legal standard to be used in the enforcement of the industries in the Durban Metropolitan Area. These bylaws set two uniform heavy metal discharge limits for all the sewage works in the Metropolitan Area based on the size of the sewage works.

Owing to the varying standards enforced by the different Local Authorities on Metal Finishing Industries, these industries did not initially fully comply with the new discharge standards set in the Sewage Disposal Bylaws. Also, high levels of heavy metals being discharged to the various treatment works caused some of the treatment works sludge to be non compliant with the new standards set by the Department of Water Affairs and Forestry. There were also numerous illegal discharges of untreated heavy metal industrial effluents to the sewer and storm water catchments.

A series of different techniques was used to regulate these industries to help them achieve environmental compliance.

This paper was originally presented at the 2004 Water Institute of South Africa (WISA) Biennial Conference, Cape Town, South Africa, 2-6 May 2004.

* To whom all correspondence should be addressed.

甶+2731 302 4685; fax: +2731 3024747 ;

e-mail: dalebr@dmws.durban.gov.za

\section{Pollution control techniques}

\section{Metal finishing guideline document}

The Metal Finishing Guideline Document (1) was developed to produce a Best Available Technology (BAT) in effluent treatment for the Metal Finishing Industries to meet. This document was developed by the eThekwini Municipality and agreed on by representatives of the metal finishing industries, the Durban Chamber of Commerce and Industry.

The guideline document represents a guide to practical treatment processes, process control methodology and engineering design. It also sets out how the Department will exercise controls to ensure compliance with effluent quality limits. Adoption of the recommendations given in this guideline document provides for both industry compliance with effluent standards and the Department's statutory control function, without the latter entailing excessive costs.

The document consists of five sections and are as follows:

A. Correct treatment process chemistry

B. Correct process control

C. Correct engineering design

D. Metro requirements for effluent compliance and monitoring

E. Methods of sludge handling, storage and disposal

Sections A through $\mathrm{C}$ set out the minimum criteria that are required to pre-treat the effluent and the design of the effluent treatment plant. The requirement for effluent compliance and monitoring in section D was where the biggest challenge lay for both industry and Municipality. This represented a shift of responsibility for control and monitoring of the industry's effluent from the Municipality to the Industries. The Municipality's role was now only to do spot monitoring to determine compliance. 
The Guideline Document prescribed the minimum standard to be applied to all metal finishing industries in the Municipality, such that ad-hoc sampling by the municipality on a random basis of a slow, even discharge of effluent could be made. This sampling was based on full cost recovery with the number of samples per month determined by an audit that was carried out on the industry. The frequency of the sampling ranged from one to eight per month depending on the company's compliance with the Guideline Document and bylaw discharge limits.

\section{Company audits}

In 2001 management of the Pollution Division appointed a technician to be the project leader so as to ensure a single accountable person and equal treatment of all 65 metal finishing industries across the municipality.

This ensured equal evaluation in the audits, which were to be carried out on the metal finishing industries. It also helped the industries as they had a contact person in the Municipality who could help them with their queries.

The purpose of the audits was to monitor the company's compliance with the Guideline Document and thus set the sample frequency for the industry. As the samples were taken on a cost recovery basis, this constituted a monetary incentive for the industry. The more they complied, the less frequently they were sampled and the less they would have to pay. Typical cost of a sample ranged from R193 to R238.

The audit was developed by the eThekwini Municipality, but was presented to the Metal Finishing Association (2), for approval and comment before being implemented.

The structure of the audit was set out in seven sections as follows:

- General Issues, this section covers the process tanks, piping, roofing, effluent tanks, bunding and floors.

- Correct Effluent Treatment Process Control

- Correct Engineering Design for Effluent Tanks

- Sludge Disposal

- Cleaner Production/ Waste minimisation

- Effluent Compliance and Monitoring

- General Site Appearance

- Compliance with the Municipal Effluent discharge standards.

Each section received a rating and weighting score as per Table 1.

\begin{tabular}{|c|c|c|c|c|c|c|}
\hline & & ing an & $\begin{array}{l}\text { TABLE } \\
\text { d weigl }\end{array}$ & & scores & \\
\hline & & & & $\operatorname{tin}$ & & \\
\hline $\begin{array}{c}1 \\
\text { Unacceptab }\end{array}$ & & $\begin{array}{r}\text { Impro } \\
\text { ne }\end{array}$ & $\begin{array}{l}2 \\
\text { vement } \\
\text { eded }\end{array}$ & & $\begin{array}{c}3 \\
\text { cceptable }\end{array}$ & $\begin{array}{c}4 \\
\text { Excellent }\end{array}$ \\
\hline & & & Weight & & & \\
\hline $\begin{array}{c}1 \\
\text { Not } \\
\text { important }\end{array}$ & $\begin{array}{r}\text { Mc } \\
\text { in }\end{array}$ & $\begin{array}{l}2 \\
\text { erately } \\
\text { ortant }\end{array}$ & $\begin{array}{c}3 \\
\text { Import }\end{array}$ & & $\begin{array}{c}4 \\
\text { Crucial }\end{array}$ & $\begin{array}{c}5 \\
\text { Mandatory }\end{array}$ \\
\hline
\end{tabular}

The rating score is as assessed by the auditor, and the weighting score was set depending on the importance of the section for compliance with the Guideline Document or Sewage Disposal Bylaws. Each section was finally scored by multiplying the rating and weighting scores. These were then added to give an audit score, which was further added to the compliance score (section $\mathrm{H}$ ), giving the total score. This score was then used to determine the monthly sample frequency of the company depending on where the score landed in Table 2.

\begin{tabular}{|c|c|}
\hline \multicolumn{2}{|c|}{ TABLE 2 } \\
Method used to calculate sample frequency \\
\hline Audit Score & Sample Frequency \\
\hline $82 \%-100 \%$ & 1 \\
$67 \%-81 \%$ & 2 \\
$55 \%-66 \%$ & 4 \\
$0 \%-54 \%$ & 8 \\
\hline
\end{tabular}

Results from the audits carried out on the Metal Finishing industries in 2002 and 2003 respectively have shown a great improvement in compliance with both the Guideline Document and the standards of effluents discharged to sewer. The table below shows the migration of companies from the higher sample frequency bracket to the lower frequency bracket.

\begin{tabular}{|c|c|c|}
\hline \multicolumn{3}{|c|}{ TABLE 3 } \\
Sample frequency of companies \\
\hline $\begin{array}{c}\text { Frequencyl } \\
\text { month }\end{array}$ & 2002 & 2003 \\
\hline 1 & 7 & 27 \\
2 & 13 & 21 \\
4 & 29 & 6 \\
8 & 2 & 2 \\
\hline
\end{tabular}

Moreover, the number of analyses carried out over the project period has dropped significantly, showing again that the companies are complying with the standards set. The table below shows the number of analyses carried out for each year, with the corresponding number of out of specification results.

\begin{tabular}{|c|c|c|c|}
\hline \multicolumn{4}{|c|}{ TABLE 4 } \\
Number of analysis \\
\hline $\begin{array}{c}\text { Year } \\
\text { Period }\end{array}$ & $\begin{array}{c}\text { Total number } \\
\text { of analyses }\end{array}$ & $\begin{array}{c}\text { Number of } \\
\text { out of } \\
\text { specification } \\
\text { analyses }\end{array}$ & $\begin{array}{c}\text { Percentage } \\
\text { non- } \\
\text { compliance }\end{array}$ \\
\hline 1999 & 421 & 128 & 30 \\
2000 & 1969 & 228 & 11 \\
2001 & 1769 & 818 & 46 \\
2002 & 1314 & 526 & 40 \\
2003 & 893 & 277 & 31 \\
\hline
\end{tabular}

From the results above, 1999 and 2000 show that although analyses were being done on the metal finishing industries, there was not a 
uniform standard of enforcement being applied to the industries. After the initial audits were carried out in 2001, a realistic picture was obtained of the metal finishing industry's compliance with the Bylaws discharge standards. The number of out of specification results increased, indicating that the correct analysis of the metal finishing industrial discharges was now done. Over the next couple of years these out of specification results have dropped as the industries have started to comply with the Guideline Document. The numbers of samples taken has also decreased as the industries have bettered their audit score, which determines the sampling frequency.

\section{Company recognition}

The Municipality decided in 2003 to issue an achievement award to the 3 companies who achieved the best results in the environmental audits. It was seen that the municipality should recognise the efforts of the companies that showed the best compliance with all aspects of the Guideline Document, as well as implementing cleaner production and waste minimisation techniques. These achievement awards were co presented with the Durban Chamber of Commerce and Industry in recognition of their role in the project. In terms of the municipality's strong focus on sustainability, the aim was that the achievement award could be used by the industry as a marketing tool to show their environmental status and gain extra business in this way in both local and international markets.

\section{Co-operative arrangements}

Another technique used by the Municipality is that of the co-operative contract. This was a unique situation with a single company that presented itself to Council. It was felt that a cooperative arrangement, rather than permit withdrawal and closing of the company sewer, was an alternative that should be pursued. The agreement was in the form of a cooperative contract of work to be done to ensure compliance with the Bylaws, a deal facilitated by members of the steering committee of the Metal Finishing Association as well the Cleaner Production in the Metal Finishing Industry project (3) and the Municipality.

The agreement entailed a review of the plant, which resulted in a project management report. This listed the work to be done, cost of such work and an agreed time frame in which it was due to be completed. The project scope also included training of staff, effluent pre-treatment and groundwater pollution measures. Once agreement was reached between the company, Council, the Metal Finishing Association steering committee and representatives of the Cleaner Production in the Metal Finishing Industry Project, the project scope was turned into a formal agreement between Council and the industry concerned.

To date the company has removed all the old plating lines, the contaminated floor has been lifted and it has installed the first of the new plating lines using a cyanide-free plating method.
Figure 1

Achievement award

Achievement award
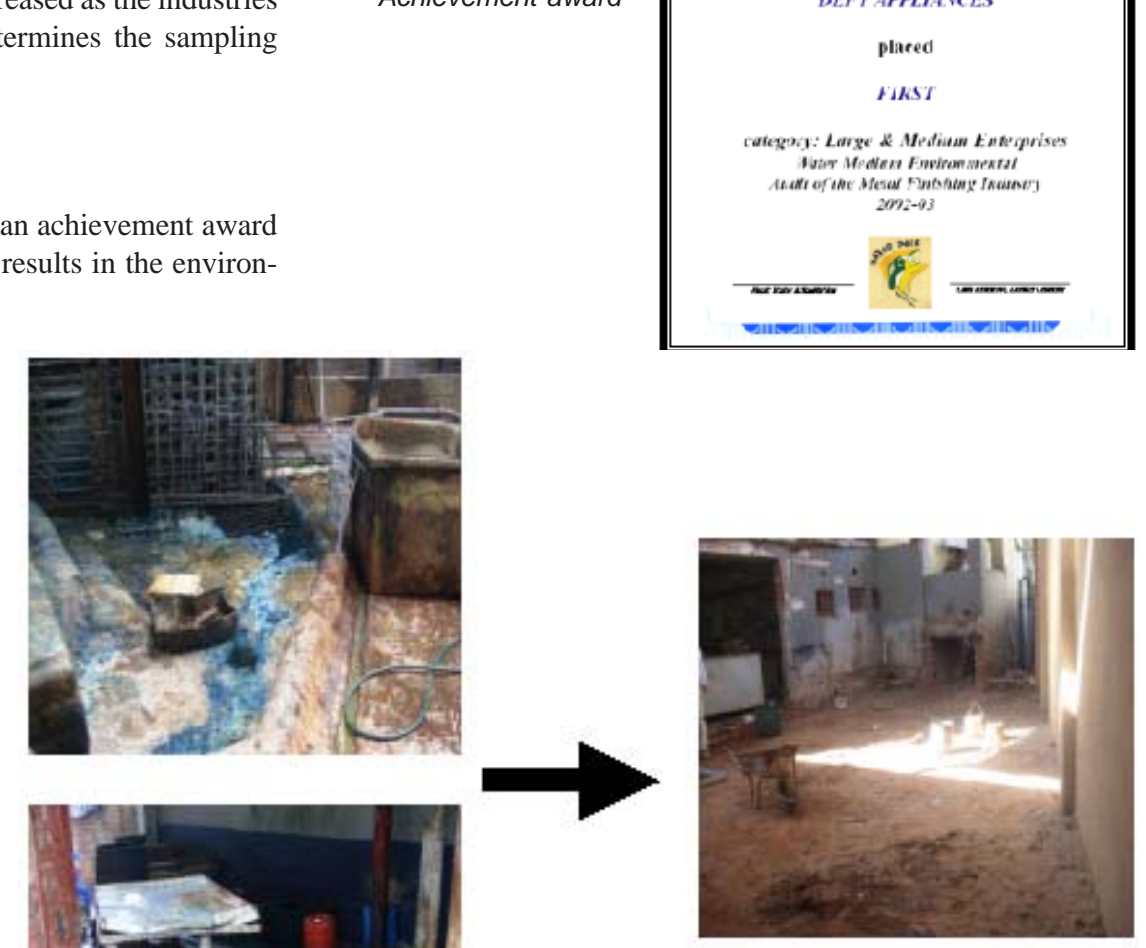

Figure 2

Photographs showing the progress of the company. Left two photographs shows the old state of the company, right photographs shows the old plating area cleaned and floors removed.

\section{External factors}

There were a number of external factors that played an important role in helping to achieve successful results in this project. The three most influential factors were the Waste Minimisation Clubs run by the Natal University Pollution Research Group, the Cleaner Production in the Metal Finishing Industries Project under leadership of Michael Koefoed initiated by the Danish Ministry of Environment and Energy and the formation of the Metal Finishing Association.

The first Waste Minimisation Club that was held was attended by 29 companies. During the course of this initial club the companies saved in the region of 2 million rand. This spurred on the rest of the industries to follow suit and to start implementing cleaner production and waste minimisation techniques (4).

At roughly the same time, the Cleaner Production in the Metal Finishing Industries Project was launched in South Africa. This project was to promote cleaner production in the metal finishing industries. It provided international expertise to the companies to achieve cleaner production in their factories. A number of demonstration plants were developed under this project. These plants showed practical methods of cleaner production and waste minimi- 


\section{Southern Wastewater Sea Outfall}

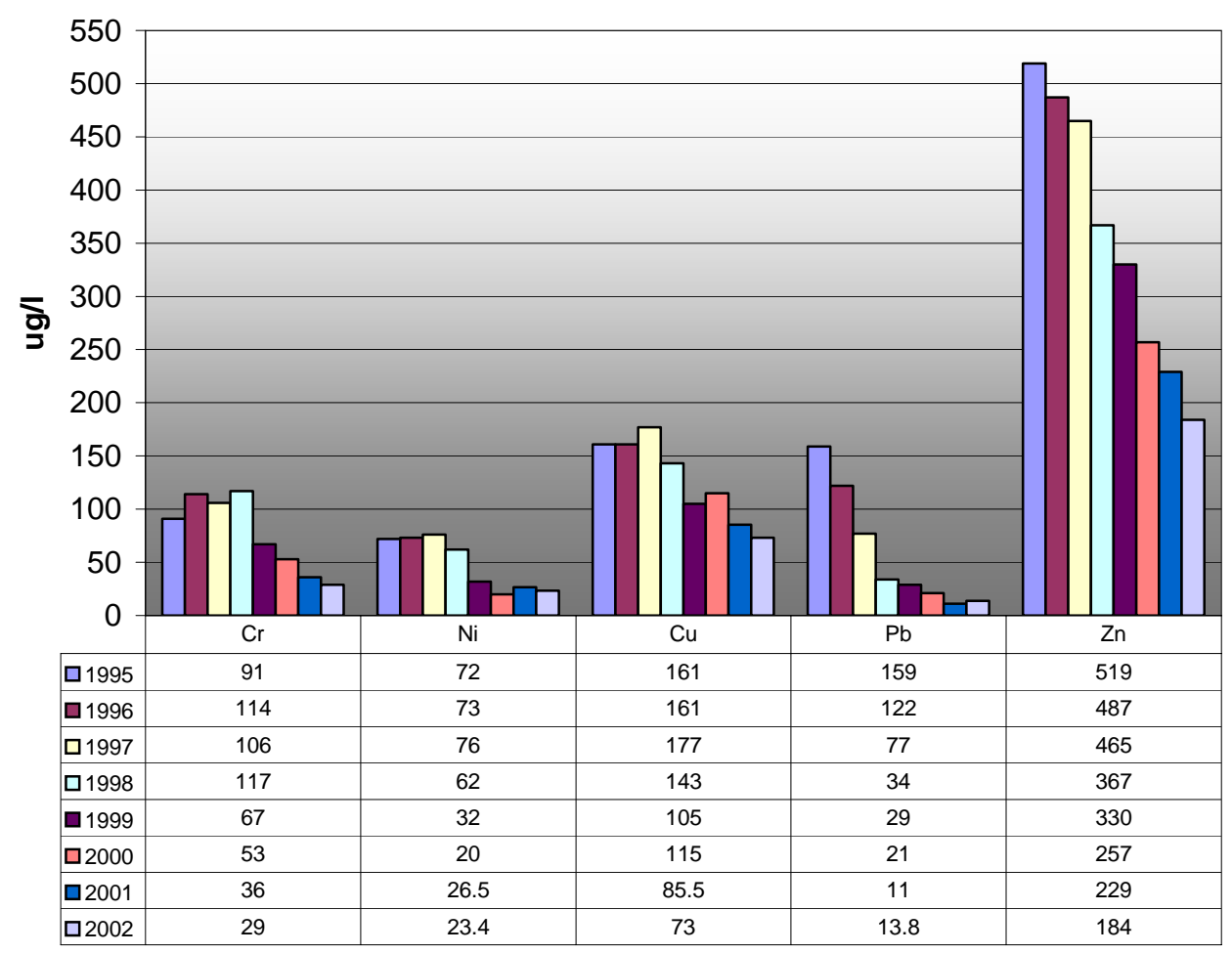

Figure 3

Graph showing the decline of heavy metals discharged to sea.

\section{Umbilo Wastewater Treatment Works}

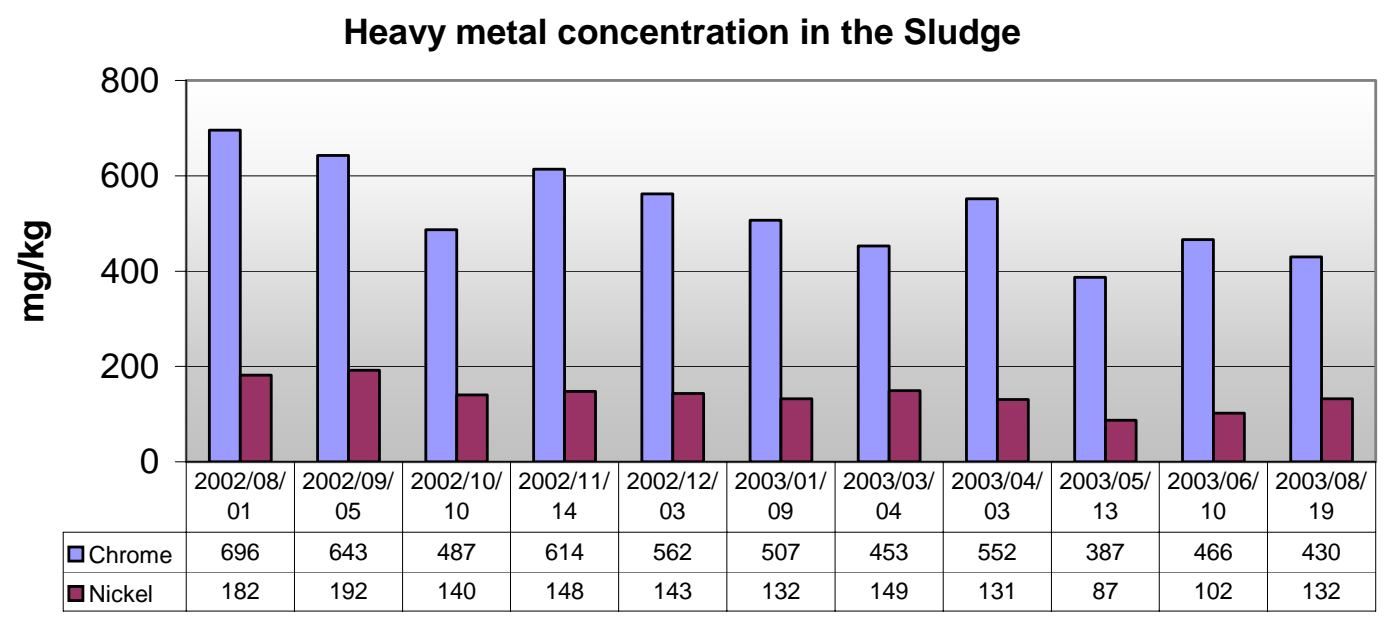

Figure 4

Graph showing the decline of the heavy metal concentration in the sludge

zation, in some cases saving companies up to $95 \%$ of water and $60 \%$ chemical savings (3).

The Metal Finishing Association of Kwazulu Natal, is an association that represents all types of metal finishing companies. It was formed in July 2000. The association acts as a broker for the industries with the Municipality in forming agreements, such as the audit form that was used to audit their industries.

\section{Results}

Southern Wastewater Treatment Works and the Umbilo Wastewater Treatment works receive the bulk of the metal finishing effluents in the Municipality. It can be seen from the Figure 3 below that there is a decline in the concentration of the heavy metals that have been discharged via the sea outfall. The effect that this project has had on the metal discharges can be seen via the decrease of the Chrome, Nickel and Copper from the pre 1999 plateau to the continual decline after 1999.

Figure 4 shows the decline in the heavy metal concentrations of Chrome and Nickel recorded in the sludge at the Umbilo Wastewater Treatment works over the past year. It indicates that there has been success in reducing the discharges of heavy metals to the treatment works from the metal finishing industries in the Umbilo catchment, via enforcing the guideline document standards and using the audits to assess the compliance.

However, the Municipality still believes that there are illegal discharges happening in this catchment and has embarked on a new project. This project looks at using the heavy metal uptake in the bio-filament layer of the sewer. It has been adapted from the Danish Method for use under South African conditions. 


\section{Conclusion}

The project has been running for about four years and has now come to its final stages.

The heavy metal concentrations that have been discharged to the different wastewater treatment works have been on a steady decline over the project period, thus enabling the Municipality to improve on its discharge standards as required by the Department of Water Affairs and Forestry, albeit that levels are within permit standards.

There were many barriers that had to be overcome, the most notable being that of attitude between the companies and Municipality. The municipality now has a transparent and open door working relationship with the industries, which helps to maintain co-operation and achievement of commonly agreed goals.

A hybrid of command and control, financial incentives, cooperation, use of best available techniques and cleaner production has had the desired effects on achieving receiving environmental standards and long term sustainability of the metal finishing industries in the eThekwini Municipality. It is felt that the use of any of these methods in isolation would not have achieved similar successes.

\section{Acknowledgements}

I wish to acknowledge the staff of the Pollution Division, the Danish Government, the Cleaner Metal Finishing Project and the Metal Finishing Association for their contribution to making this projects a success.

\section{References}

(1) Metal Finishing Guideline Document available from eThekwini Municipality, Pollution Division.

(2) The Metal Finishing Association in KwaZulu Natal, constituted in July 2000. Details available from the KZN MFA Secretary, 15 Stamford Court, 270 Stamford Road, Durban, 4001.

(3) The Cleaner Production Project in the Metal Finishing Industry, South Africa, Project Document, January 2000. Details available from the KZN MFA Secretary, 15 Stamford Court, 270 Stamford Road, Durban, 4001.

(4) Ms. Susan Barclay, Pollution Research Group, School of Chemical Engineering, Natal University. 